\title{
Contact-induced Variation in Tetun Dili Phonology
}

\author{
Andrei A. AVRAM \\ University of Bucharest, Romania \\ andrei.avram@lls.unibuc.ro
}

\begin{abstract}
The paper analyzes the Portuguese influence on Tetun Dili phonology, which can be can be identified at different levels. The phonemic inventory of Tetun Dili has been enriched via borrowing of several consonantal phonemes, triggering an increase in the number of phonological contrasts. Portuguese influence also accounts for the phonetic realizations of a number of consonantal and vocalic phonemes, with some allophonic rules extended even to words belonging to the native stock. Furthermore, the massive influx of Portuguese loanwords has greatly increased the number of permissible onset clusters, and lexical borrowings from Portuguese have led to the occurrence of antepenultimate stress. Finally, Portuguese influence also accounts for the considerable inter-speaker variation. These contact-induced phenomena are shown to correlate with the following factors: knowledge of Portuguese; the exo-normative vs endo-normative orientation of speakers in the case of Portuguese, i.e. towards European or Brazilian Portuguese vs. the East Timorese variety of Portuguese.
\end{abstract}

Keywords: Tetun Dili; Portuguese; variation; phonological restructuring

\section{Povzetek}

Prispevek analizira portugalski vpliv na fonologijo jezika tetun dili, ki ga je mogoče prepoznati na različnih ravneh. Popis fonemov tega jezika je obogaten z izposojo več soglasniških fonemov, kar je sprožilo povečanje števila fonoloških kontrastov. Portugalski vpliv so tudi fonetične realizacije številnih soglasniških in zlogotvornih fonemov, katerih alofonska pravila so razširjena tudi na domače besede. Poleg tega je močan pritok portugalskih izposojenk močno povečal število dovoljenih soglasniških nizov v zaprtem zlogu in spodbudil naglaševanje na predzadnjem zlogu. Nenazadnje pa portugalski vpliv predstavlja precejšnje razlike med govorci. Pokazalo se je, da omenjeni pojavi posledično vplivajo na znanje portugalščine ter na ekso-normativno oziroma endo-normativno usmerjenost govorcev $v$ primeru portugalščine, $t j$. uporabo evropske ali brazilske portugalščine oziroma uporabo vzhodno-timorske različice portugalščine.

Ključne besede: tetun dili; portugalščina; sprememba; fonološko prestrukturiranje 


\section{Introduction}

Previous work on the Portuguese influence on Tetun Dili (e.g. Hajek, 2007; Williamsvan Klinken \& Hajek, 2016; Avram, 2018; Williams-van Klinken \& Hajek, 2018) was mainly concerned with the morphology, syntax, and lexicon. The present paper analyzes the Portuguese impact on Tetun Dili phonology.

The sources consulted for Portuguese are: (i) European Portuguese - Mateus \& D'Andrade (2000); Massini-Cagliari et al. (2016); (ii) Brazilian Portuguese - Seara et al. (2011); Massini-Cagliari et al. (2016); (iii) Timor-Leste Portuguese - de Albuquerque (2010b, 2011b, 2011c, 2012, 2014a, 2014b, 2015).

The corpus of Tetun Dili examples is from: grammars (Williams-van Klinken et al., 2002a, 2002b); dictionaries (Costa, 2001a; Hull, 2002; Loch \& Tschanz, 2005; Hull, 2006; Manhitu, 2007); phrasebooks (Costa, 2001b; Saunders, 2004; Hajek \& Tilman, 2008); theses and dissertations (de Araújo e Corte-Real, 1990; de Albuquerque, 2011a; Greksáková, 2018); papers (Hull, 2000; Esperança, 2001; Chen, 2015). The examples are kept at a reasonable minimum. The citation forms of Tetun Dili examples are given in the current standard orthography and their transcription is in IPA.

The paper is organized as follows. Section 2 outlines the language situation in East Timor, with a focus on Tetun Dili and Portuguese. Section 3 is a brief overview of the phonologies of Tetun Terik and Tetun Dili. Section 4 is concerned with the imported consonantal phonemes. Section 5 looks at the new phonological contrasts. Section 6 deals with the phonetic realizations of the imported phonemes. Section 7 discusses a number of selected allophonic rules. Section 8 analyzes developments in syllable structure. Section 9 focuses on stress placement. Section 10 summarizes the findings.

\section{Language situation in East Timor: Tetun Dili and Portuguese}

Tetun Dili ${ }^{1}$ is spoken in East Timor ${ }^{2}$. Tetun Dili is one of the two official languages of East Timor, alongside Portuguese. Williams-van Klinken et al., 2002b: 5) write that Tetun Dili is spoken by "some $60-70 \%$ of the population of East Timor", while de Albuquerque (2010a, p. 30) states that it is "falado por mais de $80 \%$ da população" [= spoken by more than $80 \%$ of the population, translation mine]. It is estimated that some $36 \%$ are first-language speakers and some that $60 \%$ speak Tetun Dili as a second language (Williams-van Klinken et al., 2002b, p. 5).

The status of Tetun Dili is a matter of some dispute in the literature (see also Avram 2005a), with various authors employing different labels: "pidgin" Smith (1995, p. 360);

\footnotetext{
${ }^{1}$ Also known as Tetum-Praça/Tetun-Prasa.

${ }^{2}$ The official name of the country is Timor Loro Sa'e in Tetun and Timor-Leste in Portuguese, respectively.
} 
"creole" (Ross, 2017); "an Austronesian language" (Williams-van Klinken et al., 2002a, 2002b); "an Austronesian language with many Portuguese loans" (Chen, 2015, p. 29); "a koiné with heavy Portuguese lexical influence" (Greksáková, 2018, p. 82).

As for Portuguese, it is spoken only by $36 \%$ of East Timor's population. In addition to the difference in the number of speakers, there is a clear asymmetrical power relationship between Tetun Dili and Portuguese (Taylor-Leech, 2009; de Albuquerque, 2010a, 2018; Greksáková, 2018). Although official language policies favour the promotion and development of Tetun Dili as a nation-building instrument, knowledge and use of Portuguese still carries considerable prestige (Taylor-Leech, 2007, 2009; Ross, 2017). From a sociolinguistic perspective, there is a continuum of Portuguese varieties. According to de Albuquerque (2011b, p. 70) this can be represented as follows:

\begin{tabular}{|l|l|}
\hline European Portuguese norm & popular Portuguese \\
urbanized areas & rural \\
Dili, Baucau & border with Indonesia \\
& Viqueque, Oecussi \\
\hline
\end{tabular}

Figure 1: Portuguese continuum in Timor-Leste (de Albuquerque 2011b, p. 70)

In the above representation, "popular Portuguese" is, to quote Thomaz (2010, p. 39), "das Portugiesische von Timor, das von Personen mit geringer Bildung gesprochen wird" [= the Portuguese of Timor, which is spoken by persons with little education, translation mine]. De Albuquerque (2011b, p. 75, n. 5) defines it as "a subvariedade do PTL [= português de Timor-Leste] que o falante aprendeu de maneira não formal e [...] sofre maior influência da língua materna do falante, ou seja, mais distante da norma europeia" [= a subvariety of Portuguese which the speaker acquired in a non formal manner and which [...] undergoes more influence from the speaker's mother tongue, namely more distant from the European norm, translation mine]. In fact, the picture is more complex. Neither Thomaz (2010) nor de Albuquerque (2011b) mention Brazilian Portuguese. However, as noted by Hajek \& Tilman (2008, p. 181), "you'll hear at least three different Portuguese accents in East Timor [...] Portuguese as spoken by most Timorese" [...] European Portuguese [and] Brazilian Portuguese". The latter variety is a relatively new addition to the Portuguese continuum in East Timor, a consequence of post-independence developments, given that Brazil runs a wide range of support programs in the country, including for the teaching of Portuguese. 


\section{Phonology of Tetun and Tetun Dili}

Historically, Tetun Dili developed out of Tetun Teturik, spoken in the south of the island of Timor as well as in the southwest, i.e. the area of the East Timor - West Timor border ${ }^{3}$. Tetun Terik and Tetun Dili differ in a number of respects in their phonology, morphology, syntax, and lexicon, as shown by e.g. Williams-van Klinken et al. (2002b, pp. 53-56). In what follows, the focus is on the differences between these two major varieties of Tetun in their inventories of phonemes.

There is consensus among authors such as das Dores (1907), Troeboes et al. (1987, p. 14-28), Taryono et al. (1993, p. 25-34), van Klinken (1999), Hull (2000, p. 167, p. 189), Costa (2001a, p.: 23-22), Esperança (2001, p. 50-60), Thomaz (2002, p. 52) with respect to the inventory of consonant and vocalic phonemes of Tetun Terik. As shown in Table 1 , the system of vocalic phonemes of Tetun Terik is relatively simple, consisting of $/ \mathrm{i} /$, $/ \mathrm{u} /, \mathrm{e} /, / \mathrm{s} /$ and $/ \mathrm{a} /$ :

Table 1: Tetun Terik: Vocalic phonemes

\begin{tabular}{lcc}
\hline & front & back \\
\hline high & $\mathrm{i}$ & $\mathrm{u}$ \\
high mid & $\mathrm{e}$ & \\
low mid & & $\mathrm{J}$ \\
low & $\mathrm{a}$ & \\
\hline
\end{tabular}

Tetun Terik also has a relatively small number of consonantal phonemes. The system of consonant phonemes is set out in Table 2 below:

Table 2: Tetun Terik: Consonantal phonemes

\begin{tabular}{lcccc}
\hline & bilabial & alveolar & velar & glottal \\
\hline stops & $\mathrm{b}$ & $\mathrm{t}$ & $\mathrm{k}$ & ? \\
& $\mathrm{d}$ & & \\
fricatives & $\mathrm{m}$ & $\mathrm{n}$ & $\mathrm{h}$ \\
nasals & & $\mathrm{r}$ & \\
tap & $\mathrm{w}$ & $\mathrm{l}$ & \\
approximants & $\mathrm{w}$ & \\
\hline
\end{tabular}

The inventory of consonantal phonemes of Tetun Dili is discussed by Costa (2001a, p. 22), Hull (2000, p. 167), Williams-van Klinken et al. (2002a, p. 11, 2002b, p. 12), de

\footnotetext{
${ }^{3}$ Which is part of the Republic of Indonesia.
} 
Albuquerque (2011a, p. 77, p. 83), a.o. Several authors posit a so-called "minimal inventory" (Hull, 2000) or "Umgangslautung" [= colloquial pronunciation, translation mine] ${ }^{4}$ (Saunders, 2004). According to Hull (2000, p. 189) this consists of "11 consonantal phonemes, given the loss of /'/ and the assimilation of /w/ to /b/" (Hull, 2000, p. 189), as shown in Table 3:

Table 3: Tetun Dili: Consonantal phonemes (minimal inventory)

\begin{tabular}{lcccc}
\hline & bilabial & alveolar & velar & glottal \\
\hline stops & $\mathrm{p}$ & $\mathrm{t}$ & $\mathrm{k}$ & \\
& $\mathrm{b}$ & $\mathrm{d}$ & & \\
fricatives & & $\mathrm{s}$ & & $\mathrm{h}$ \\
nasals & $\mathrm{m}$ & $\mathrm{n}$ & & \\
tap & & $\mathrm{r}$ & \\
approximants & & $\mathrm{l}$ & \\
\hline
\end{tabular}

The so-called "maximal inventory" (Hull, 2000) or "Hochlautung" [= standard pronunciation, translation mine $]^{5}$ (Saunders, 2004) contains 22 consonantal phonemes (Hull, 2002, p. 189; Williams-van Klinken et al., 2002a, p. 8, 2002b, p. 10):

Table 4: Tetun Dili: Consonantal phonemes (maximal inventory)

\begin{tabular}{|c|c|c|c|c|c|c|c|}
\hline & bilabial & labio-dental & alveolar & alveo-palatal & palatal & velar & glottal \\
\hline \multirow[t]{2}{*}{ stops } & $p$ & & $\mathrm{t}$ & & & $\mathrm{k}$ & \\
\hline & $b$ & & $d$ & & & $g$ & \\
\hline \multirow[t]{2}{*}{ fricatives } & & $f$ & s & $\int$ & & & h \\
\hline & & v & $\mathrm{z}$ & 3 & & & \\
\hline nasals & $\mathrm{m}$ & & $n$ & & $n$ & & \\
\hline tap & & & r & & & & \\
\hline trill & & & $r$ & & & & \\
\hline liquid & & & 1 & & $\Lambda$ & & \\
\hline glide & w & & & & j & & \\
\hline
\end{tabular}

\footnotetext{
4 Used "von der großen Mehrheit der Bevölkerung" [= by the large majority of the population, translation mine] (Saunders, 2004, p. 16).

${ }^{5}$ Saunders (2004, p. 16) writes that "die Hochlautung wird vorwiegend von gebildeten Bewohnern der Hauptstadt Dili verwendet" [ = the standard pronunciation is mainly used by educated inhabitants of the capital Dili, translation mine].
} 
The maximal inventory in Table 4 is the consequence of the fact that Tetun Dili has borrowed a number of consonantal phonemes, the topic of the next section.

\section{Imported consonantal phonemes}

Tetun Dili has increased the number of consonantal phonemes, in comparison with Tetun Terik of which it is historically an offshoot. The additional consonantal phonemes are from Malay and, in particular, Portuguese.

Costa (2001a, p. 24) writes that "foram, ainda, introduzidas no tétum [...] consoantes, em especial devido à importação de palavras [...], predominantemente de origem portuguesa" [= due especially to the import of words of [...] predominantly of Portuguese origin, consonants were also introduced into Tetun, translation mine]: /p/, /g/, /v/, /z/ and /3/. However, according to other authors, the number of the imported consonantal phonemes is larger. Hull (2000, p. 189), for instance, lists nine "(Malay and/or Portuguese-derived) consonantal phonemes": /g/, /n/, / //, /p/, /r/, /v/, /z/, /f/ and /3/. Williams-van Klinken et al. (2002b, p. 10) attribute to Portuguese exclusively the increase in the number of consonantal phonemes of Tetun Dili, writing that "Portuguese loans are responsible for introducing the phonemes /p g v z $3 \mathrm{n} K \mathrm{r} /$ ". De Albuquerque (2011a, p. 85) writes that "alguns dos sons [do] Malaio e [do] português [...] foram incorporados à fonologia" [= some of the sounds of Malay and Portuguese [...] were incorporated into the phonology, translation mine]: /p/, /v/, /z/ and g/.

As can be seen, there are discrepancies in the number of consonantal phonemes of foreign provenance, i.e. from Malay and Portuguese. One of the factors accounting for these discrepancies is the differential extent to which these imported consonantal phonemes have been integrated into the phonology of Tetun Dili. According to de Albuquerque (2011a, p. 86), "p/ e /g/ já foram incorporados de maneira efetiva" [= /o/ and /g/ have already been effectively incorporated, translation mine], whereas "/v/ e /z/ "encontram-se limitados a empréstimos lusófonos" [= are limited to Lusophone loanwords, translation mine]. Note, however, the inconsistency: /v/ and /z/ are also listed among the imported consonantal phonemes which are characterized as "sendo produtivos e aparecendo em alguns vocábulos nativos" [= being productive and occurring in some native words] (de Albuquerque, 2011a, p. 85). Other consonants, i.e. $\left[\int, 3, \mathrm{n}, \mathrm{K}\right]$ "foram emprestadas da língua portuguesa e não foram incorporadas" [= have been borrowed from the Portuguese language and have not been incorporated, translation mine] and "permanecem limitadas somente aos itens lexicais de origem lusófona" [= remain confined to lexical items of Lusophone origin, translation mine] (de Albuquerque, 2011a, p. 87). On de Albuquerque's (2011a) analysis, some of the imported consonantal phonemes have a restricted distribution, occurring only Portuguese loanwords. 
A second factor is the considerable inter-speaker variation with respect to the occurrence of the imported phonemes. According to Williams-van Klinken et al. (2002b, p. 10), "many speakers do not have the full set of consonant phonemes". The only reason for the absence of some of the imported consonantal phonemes in the Tetun Dili of such speakers mentioned in the literature is the influence of the L1s of the speakers (e.g. Williams-van Klinken et al., 2002b, p. 10; de Albuquerque, 2011a). However, the East Timor variety of Portuguese must also have played a role. Indeed, one of the characteristics of the phonology of East Timor Portuguese is the absence of the following phonemes from its phonemic inventory: /p/, /v/, / /, /3/, /n/, / / / (de Albuquerque, 2010b, pp. 276-277, 2011b, pp. 70-72, 2011c, pp. 234-235; Thomaz, 2010 , p. 39). In other words, the local variety of Portuguese functions as a "filter" and the aforementioned consonantal phonemes do not make it into Tetun Dili.

\section{Phonological contrasts}

For Tetun Dili speakers with the maximal inventory of consonantal the massive influx of Portuguese loanwords has led to the emergence of new phonological contrasts:

(1) a. $/ f /-/ v /$

b. $/ \mathrm{f} /-/ \mathrm{b} /$

c. $/ \mathrm{f} /-/ \mathrm{p} /$

d. $|s /-| z \mid$

e. $/ \mathrm{s} /-/ \mathrm{S} /$

f. $\mid z /-/ 3 /$

g. $/ \mathrm{n} /-/ \mathrm{n} /$

h. $/ \mid /-/ K /$

However, according to Williams-van Klinken et al. (2002b, p. 10), "especially for those who are not native speakers of Tetun Dili, there is the possibility of a merger for: $/ \mathrm{v} /-/ \mathrm{b} /, / \mathrm{J} /-/ \mathrm{s} /, / 3 /-/ \mathrm{z} /, / \mathrm{n} /-/ \mathrm{n} /$, and $/ \mathrm{K} /-/ \mathrm{l} /{ }^{\prime \prime}$. In this case again, the absence of these phonological contrasts may be attributed to the absence of the consonantal phonemes $/ \mathrm{v} /, / \mathrm{J} /, / 3 /, / \mathrm{n} /, / \mathrm{K} /$ in the locally spoken variety of Portuguese. 


\section{Phonetic realizations of imported phonemes}

\subsection{Nasal vowels}

Some speakers of Tetun Dili denasalize vowels ${ }^{6}$ in Portuguese loanwords. This is captured by the rule in (2) and illustrated by the example in (3):

(2) $\widehat{\mathrm{V}} \rightarrow[$-nasal $]$

(3) jardín [zardin] 'garden' < Portuguese jardim

Denasalization of vowels is also a characteristic of East Timor Portuguese, as shown by de Albuquerque (2010b, p. 278, 2011c, p. 235). Consider the examples below:

(4) a. East Timor Portuguese amanhã [amanjan] 'tomorrow'

b. East Timor Portuguese ontem [ontem] ${ }^{7}$ [onten] 'yesterday'

As can be seen in the examples under (3) and (4) the denasalized vowel is followed by a non-etymological nasal. De Albuquerque (2011c, p. 235) attributes denasalization in East Timor Portuguese to the influence of Tetun, claiming that "ha com frequência [...] a inserção de un [n] epentético" [= the insertion of an epenthetic [n] frequently occurs, translation mine] since Tetun "ha um grande número de substantives terminados com um sufixo $-n$ " [= has a large number of nouns ending in a suffix $-n$, translation mine]. In fact, denasalization is an instance of unpacking ${ }^{8}$, whereby "the phonetic features present in a single segment are split into a sequence of two segments" (McColl Millar, 2015 , p. 57). In denasalization, as put by e.g. Crowley (1997, p. 46), "the original nasal and vowel features [...] are distributed over two sounds":

(5) $\overline{\mathrm{V}} \rightarrow \mathrm{V}+\mathrm{C}[+$ nasal $]$

Therefore, the Portuguese nasal vowels are reinterpreted as sequences made up of an oral vowel and a nasal consonant. As is well known, nasal vowel unpacking is widely attested ${ }^{9}$ (Crowley, 1997, p. 46; Paradis \& Prunet, 2000):

\footnotetext{
${ }^{6}$ See also section 5.2 .

${ }^{7}$ Where the occurrence of $[\mathrm{m}]$ instead of the expected $[\mathrm{n}]$ is an instance of spelling pronunciation.

${ }^{8}$ Also known as "segmentalization" (McColl Millar, 2015, p. 57).

${ }^{9}$ Nasal vowel unpacking is also taken as evidence that nasal vowels are underlyingly two segments (Paradis \& Prunet, 2000).
} 
(6) a. French camion [kamiz̃] > Bislama [kamion] 'truck'

b. French avion [avĩ̃] > Romanian avion [avion] 'airplane'

\subsection{Diphthongs}

Many of the Portuguese loanwords in Tetun Dili contain diphthongs. However, Williams-van Klinken et al. (2002b, p. 12) write that "speakers tend to reduce many of these to single vowels". This is informally expressed by the rule in (7):

(7) $V_{1} V_{2} \rightarrow V_{1}$

The following examples (from Williams-van Klinken et al., 2002b, p. 12) illustrate monophthongization:

(8) a. padeiru [padeiru] [paderu] 'baker' < Portuguese padeiro

b. tezoura [tezoura] [tezora] 'scissors' < Portuguese tezoura

Monophthongization is also attested in East Timor Portuguese (de Albuquerque, 201b, p. 279), as shown below:

(9) a. East Timor Portuguese manteiga [mantega] 'butter'

b. East Timor Portuguese vassoura [basora] 'broom'

\subsection{Labio-dentals}

Both the voiceless and the voiced labio-dentals are subject to variation. In addition to the labio-dental pronunciation these consonants are also phonetically realized as bilabial stops. Consider first /f/:

(10) $/ \mathrm{f} / \rightarrow[\mathrm{f}] \sim[\mathrm{p}]$

fila [fila] [pila] 'to return'

The same variation has been observed in East Timor Portuguese (Thomaz, 2010, p. 39; de Albuquerque 2011, p. 73):

(11) East Timor Portuguese força [forsa] [porsa] 'force' < Portuguese força

Consider next the phonetic realizations of /v/: 
(12) $/ \mathrm{v} / \rightarrow[\mathrm{v}] \sim[\mathrm{b}]$

a. xavi [Jave] [sabe] 'key' < Portuguese xave

b. servisu [servisu] [serbisu] 'work' < Portuguese serviço 'service'

This again parallels the situation in East Timor Portuguese (de Albuquerque, 2010b, p. 277, 2011b, p. 72), as illustrated by the examples below:

(13) a. East Timor Portuguese chave [save] [sabe] 'key'

b. East Timor Portuguese livro [livru] [libru] 'book'

\subsection{Tap / $/$}

According to de Albuquerque (2011a, p. 80), / $/$ is realized as [x] or [y]. Reproduced below are some of de Albuquerque's (2011a) examples:

(14) a. aeroportu [aeruportu] [aerupoxtu] 'airport' < Portuguese aeroporto

b. boraxa [bora]a] [boxasja] [buxasa] 'rubber' < Portuguese boraxa

(15) farda [fayda] [fayde] 'uniform' < Portuguese farda

De Albuquerque (2011a, p. 80) further writes that these phonetic realizations of /r/are an instance of "hipercorreção baseada na língua portuguesa" [= hypercorrection based on the Portuguese language, translation mine], without any specification as to which variety of Portuguese. Massini-Cagliari et al., 2016, p. 59) write with respect to Brazilian Portuguese that "the fricatives $[\mathrm{h}]$ and $[\mathrm{x}]$ are currently the most frequent realizations of strong $r$ ", as seen in the following examples:

(16) a. Brazilian Portuguese barriga [baxiga] 'belly'

b. Brazilian Portuguese porta [poxta] 'door'

Moreover, Massini-Cagliari et al. (2016, p. 60) explicitly mention the fact that [h] and $[\mathrm{x}]$ as phonetic realizations of the rhotic are "exclusively found in BP and do not occur in EP [= European Portuguese]". To conclude, the variation noted by de Albuquerque (2011a) in the phonetic realization of $/ \mathrm{r} /$ reflects the influence of Brazilian Portuguese. 


\subsection{Alveo-palatals}

The two alveo-palatals $/ \int /$ and $/ 3 /$ found in Portuguese loanwords frequently undergo depalatalization. Hajek \& Tilman (2008, p. 21), for instance, note that " $<\mathrm{s}>$ "sometimes pronounced as [...] ' $\mathrm{sh}$ ' at the end of a word or before a consonant". Hajek \& Tilman $(2008$, p. 21) further write that the [[] "is considered very refined and can be a good indicator that the speaker also speaks Portuguese". The examples under (17) illustrate depalatalization of $/ \mathrm{J} /$ :

$$
/ \int / \rightarrow\left[\int\right] \sim[\mathrm{sj}] \sim[\mathrm{s}]
$$

a. festa [fefta] [festa] 'party, celebration' < Portuguese festa

b. xavi [jave] [sjave] [sabe] 'key' < Portuguese xave

The same phonetic realizations also occur in East Timor Portuguese (de Albuquerque, 2010b, p. 277, 2011b, p. 72):

(18) a. East Timor Portuguese bicho [bifu] [bisu] 'worm'

b. East Timor Portuguese chá [fa] [sja] [sa] 'tea'

The next set of examples illustrates depalatalization of /3/:

$$
/ 3 / \rightarrow[3] \sim[\mathrm{zj}] \sim[\mathrm{z}]
$$

a. janela [zancla] [zjancla] [zancla] 'window' < Portuguese janela

b. justisa [3ustisa] [zjustisa] [zustisa] 'justice' < Portuguese justiça

East Timor Portuguese also exhibits depalatalization of /3/ (de Albuquerque, 2010b, p. 277, 2011b, p. 72, 2011c, p. 235). Consider the examples below:

(20) a. East Timor Portuguese ajuda [azuda] [azuda] 'help'

b. East Timor Portuguese hoje [0ze] [oze] 'today'

c. East Timor Portuguese já [zja] 'already'

The Tetun Dili [sj] and [zj] reflexes of $/ \mathrm{J} /$ and $/ 3 /$ constitute examples of unpacking. As shown by Operstein (2010, pp. 150-151), unpacking of $/ \int /$ in particular is crosslinguistically widely attested. Below are two of Operstein's (2010, p. 151) examples:

(21) a. Italian scienza [ $\left.\int \varepsilon n t s a\right]>$ Piedmont Italian [sjensa] 'science'

b. $16^{\text {th }}$-c. English ash [æ] $>$ Welsh <aiss> 


\subsection{Palatals}

Depalatalization may also affect $/ \mathrm{n} /$ and $/ K /$ in Portuguese loanwords. The former has up to four possible phonetic realizations:

$$
/ \mathrm{n} / \rightarrow[\mathrm{n}] \sim[\mathrm{nj}] \sim[\mathrm{jn}] \sim[\mathrm{n}]
$$

a. banhu [banu] [banjo] 'bath' < Portuguese banho

b. linha [lina] [lijna] [lina] 'line' < Portuguese linha

Depalatalized realizations of $/ \mathrm{n} /$ are also reported to occur in East Timor Portuguese (de Albuquerque, 2010b, p. 277, 2011b, p. 72, and 2011c, p. 235). While in some cases, as in (23a), there is [n] [nj] variation, in others, as in (23b), [nj] this appears to be the only phonetic realization:

(23) a. East Timor Portuguese bonitinho [bonitinu] [bonitinju] 'nice-DIM'

b. East Timor Portuguese rascunho [raskunju] 'sketch'

As for $/ K /$, its various phonetic realizations are illustrated in the following example:

(24) $/ K / \rightarrow[K] \sim[j]] \sim[1]$

pilha [piKa] [pijla] [pila] 'battery' < Portuguese pilha

Similar cases are attested in East Timor Portuguese (de Albuquerque, 2010b, p. 276, 2011b, p. 72, 2011c, pp. 234-235).

(25) a. East Timor Portuguese olho [oKu] [olju] [ojlu] 'oil'

b. East Timor Portuguese espelho [espelju] [espelu] 'mirror'

Depalatalization of both $/ \mathrm{n} /$ and / $K /$ is yet another instance of unpacking, very frequent cross-linguistically (Operstein, 2010, p. 150; McColl Millar, 2015, p. 57). The former is illustrated in (26) and the latter in (27):

(26) a. $16^{\text {th }}$-c. French cicogne [sikon] $>$ Breton <cicoing > 'stork'

b. Spanish cañon [kanon] > English canyon [ $\mathrm{k}^{\mathrm{h}}$ ænjən] 'canyon'

(27) a. Spanish botella [boteKa] > Central Basque boteila [botejla] 'bottle'

b. Spanish ollo [oKo] > Eastern Basque oilo [ojlo] 'oil' 


\section{Allophonic rules}

\subsection{Allophone $[\mathrm{e}]$ of $/ \mathrm{a} /$}

In Portuguese loanwords one of the allophones of $/ a /$ is [e] . The phonological context in which it may occur is described by the rule in (28) and exemplified in (29):

(28) $/ \mathrm{a} / \rightarrow[\mathrm{e}] /[\text {-stress }]_{\sigma}$

(29) pilha ['pi.Ke] 'battery' < Portuguese pilha

This particular allophone may be accounted for in terms of European Portuguese influence. According to Massini-Cagliari et al. (2016, p. 62), "one of the most salient features of the EP vowel system as compared to BP is the occurrence of [e]" in "unstressed syllables", as illustrated below:

(30) European Portuguese casa ['ka.ze] 'house'

\subsection{Nasalized allophones of vowels}

Costa (2001a, p. 23) writes that in Tetun Dili "as consoantes nasais [m] e [n] nasalizam ligeiramente as vogais que as precedem" [= the nasal consonants [m] and [n] slightly nasalize the vowels which precede them, translation mine]. This is expressed by the following allophonic rule:

(31) $\vee \rightarrow[+$ nasal $] / \ldots C[+$ nasal $] \sigma$

The rule in (31) applies to both Portuguese loanwords and to words from the native stock, as shown in (32) and (33) respectively:

(32) kintál ['kĩn.ta:1] 'garden, verandah' < Portuguese quintal

(33) laran ['la.rãn] 'inside'

According to Williams-van Klinken et al. (2002b, p. 12), nasalization of vowels may also "when vowels immediately [...] follow nasals", when "they are usually nasalized", as in the example below:

(34) manu ['mã.nu] 'bird' 
Such examples suggest the allophonic rule in (35):

(35) $V \rightarrow[+$ nasal $]$ / C [+nasal $]$

However, nasalization also occurs when the vowel is not preceded by a nasal consonant, both in Portuguese loanwords (36) and in native Tetun words (37):

(36) banhu ['bã.nju] 'bath' < Portuguese banho

(37) a. aman ['ã.mãn] 'father'

b. inan ['ĩ.nãn] 'mother'

Note that in the examples above the nasalized vowel precedes a nasal consonant in the onset of the following syllable. Therefore, the rule accounting for the cases in (34) and (36)-(37) can be formulated as follows:

(38) $V$ [+stress $] \rightarrow[+$ nasal $] / \ldots \sigma[$ [ $[$ nasal $]$

The allophonic rule in (38) appears to have been borrowed from Brazilian Portuguese, in which "there is (almost) obligatory phonetic nasalization of a stressed vowel preceding a nasal onset consonant" (Massini-Cagliari et al., 2016, p. 63):

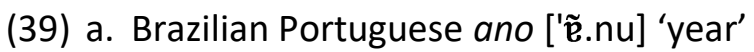

b. Brazilian Portuguese cima ['sĩ.ma] 'top'

\subsection{Allophones of $/ \mathrm{s} /$ and $/ \mathrm{z} /$}

The phonology of Tetun Dili as spoken by some of its users includes the following allophonic rule:

(40) $/ \mathrm{s} / \rightarrow[0] / \ldots C[+$ voice $]] \sigma$

As shown below, for such speakers the rule in (40) applies to both Portuguese loanwords and words from the native stock:

(41) pasta [pafta] < Portuguese pasta 
(42) a. haas [ha:]] 'mango'

b. loos [lo:]] true, correct, right'

c. tanis [tanif] 'to cry'

As noted by Williams-van Klinken (2002b, p. 10), this is "a result of Portuguese influence", without specifying the particular variety.

Similarly, /z/ is phonetically realized as [3], in the phonological context specified by the allophonic rule in (43), as illustrated by the example in (44):

(43) $/ z / \rightarrow[3] / \ldots C+$ voice $]] \sigma$

(44) dezmaia [dezmaia] 'to faint' < Portuguese desmaia

Williams-van Klinken et al. (2002b, p. 10) state that the retraction of $/ z /$ to [3] is "once again due to Portuguese influence", with no reference, however, to a particular variety. The allophonic rules in (40) and (43) can only have been borrowed from European Portuguese, in which "the coronal fricatives [s, z] palatalize in coda position to [f, 3]" (Massini-Cagliari et al., 2016, p. 58 and 59 - table 4.2), as exemplified below:

(45) a. European Portuguese deste [defti] 'of this.M'

b. European Portuguese vesgo [vezgu] 'squint-eyed'

Finally, some speakers also have the allophonic rule in (46):

(46) $/ \mathrm{s} / \rightarrow[\mathrm{z}] / \ldots$

As illustrated by the following example, the rule also operates in compounds consisting of native Tetun words:

(47) /li:s/ + /asu/ $\rightarrow$ ['li:z'asu] 'garlic' [lit. 'onion dog']

The allophonic rule in (47) is borrowed from European and/or Brazilian Portuguese.

\subsection{Allophones of /I/}

As shown in the allophonic rule below, $/ /$ is optionally velarized:

(48) $/ \mathrm{I} / \mathrm{H}] /]_{\sigma}$ 
The domain of operation of the allophonic rule above includes not only Portuguese loanwords, but also native Tetun words, as illustrated in (49) and (50) respectively:

(49) finál [fina:1] 'final' < Portuguese final

(50) nanál [nana:1] 'tongue'

This is yet another instance of a borrowed allophonic rule. As shown by MassiniCagliari et al., 2016, p. 57), "the velarized consonant [ 1 ] is the typical EP pronunciation" in coda position. Consider the following example:

(51) European Portuguese mal [mał] 'evil'

\section{Syllable structure}

\subsection{Word-initial consonant clusters}

Troeboes et al. (1987, p. 22) claim that "dalam bahasa Tetum [...] terdapat konsonan ganda, yaitu /kb/, /kd/, /kl/, /km/, /kn/ dan /kr/", which, "walaupun dituliskan dengan dua huruf, dianggap sebagai satu fonem" [= in the Tetun language there are double consonants, i.e. $/ \mathrm{kb} /, / \mathrm{kl} /$, / km/, / kn/ and $/ \mathrm{kr} /$, which, although written with two letters, are considered one phoneme, translation mine]. However, no evidence is produced in favour of their alleged mono-phonemic status. Moreover, cross-linguistically no such co-articulated consonants are reported to exist. Therefore, /kb/, /kd/, /kl/, /km/, /kn/ and $/ \mathrm{kr} /$ are consonant clusters (see also Taryono et al., 1993, p. 37).

The clusters $/ \mathrm{kb} /, / \mathrm{kd} /, / \mathrm{kl} /, / \mathrm{km} /, / \mathrm{kn} /$ and $/ \mathrm{kr} /$ are the only ones which may occur in word-initial onsets in Tetun Terik, which explains why in Tetun Dili as well "in native Tetun words, word-initial consonant clusters always begin with /k/" (Williams et al., 2002b, p. 9). As for Tetun Dili, as shown by Williams-van Klinken (2002b, p. 54), in many cases these clusters are simplified via deletion of $/ \mathrm{k} /$, as in (52), or epenthesis of [a], as in (53):

(52) Tetun Terik ktodan [ktodan] > Tetun Dili todan [todan] 'heavy'

(53) Tetun Terik kmanek [kmanek] > Tetun Dili kamanek [kamanek] 'wonderful'

The massive influx of Portuguese loanwords has led to the occurrence of a large number of new CC- clusters.

Most of the new word-initial clusters contain a stop as $C_{1}$. Particularly well represented are stop + liquid clusters. A first group consists of five stop + tap clusters: 
(54) a. /pr-/

promete 'to promise' < Portuguese promete

b. /br-/

brinku 'ear-ring' < Portuguese brinco

c. /tr-/

troka 'to exchange' < Portuguese troca

d. /dr-/

droga 'drug' < Portuguese droga

e. /gr-/

grupu 'group' < Portuguese grupo

The second group is made up of three stop + lateral clusters:

(55) a. /pl-/

plástiku 'plastic, plastic bag' < Portuguese plástico

b. /bl-/

bluza 'blouse' < Portuguese blusa

c. /gl-/

glória 'glory' < Portuguese glória

Two clusters always have /p/ as their $C_{1}$. One such cluster is /ps-/:

(56) psikolojia 'psychology' < Portuguese psicologia

The second one is /pn-/:

(57) pneu 10 'tyre' < Portuguese pneu

Contra de Albuquerque (2011a, p. 91), who claims that "na sílaba CCV, a C1 se restringe à série de oclusivas", fricative-initial word-initial clusters are also found. In these clusters $C_{1}$ is always $/ f /$ and $C_{2}$ is a liquid, i.e. the tap (58) or the lateral (59):

(58) $/ f_{\mathrm{f}-} /$

fraku 'weak' < Portuguese fraco

${ }^{10}$ The cluster /pn-/ may be broken up by epenthesis of [e] or [i]: [peneu] [pineu] (Hajek \& Tilman, 2008, p. 224). 
(59) /fl-/

flanela 'flannel' < Portuguese flanela

\subsection{Word-medial consonant clusters}

As shown by Williams-van Klinken et al. (2002b, p. 9), "word-internal consonant sequences in underived words are restricted to $/ \mathrm{kC} /$ and $/ \mathrm{mC} /$ :

(60) a. naksobu 'to fall apart'

b. hamlaha 'hungry'

Portuguese loanwords have introduced other word-medial clusters. Of these, Williams-van Klinken et al. (2002b, p. 9) only mention "(s)C+liquid sequences", i.e. CCC- clusters, as in the following example:

(61) estrada [es.'trada] ${ }^{11}$ 'road' < Portuguese estrada

However, several -CCCC- clusters occur in word-medial position:

(62) a. abstratu [ab.'stra.tu] 'abstract' < Portuguese abstrato

b. demonstrasaun [de.mon.stra.'sa.un] 'demonstration' < Portuguese demonstração

While a word-medial cluster such as /-bstr-/ directly reflects European and/or Brazlian Portuguese influence, those illustrated in (62b) and (62c) also reflect the phonetic realization of nasal vowels in Tetun Dili. Recall from section 6.1 that in Portuguese loanwords nasal vowels may undergo unpacking into $\mathrm{V}+\mathrm{C}$ [+nasal] sequences; this therefore accounts for the occurrence of the /-nstr-/ cluster in (62b) and (62c).

\subsection{Resyllabification of word-medial consonant clusters}

Williams-van Klinken et al. (2002b, p. 12) note that word-initial unstressed [i] "before $\mathrm{sC} /$ clusters [is] often absent altogether". The $/ \mathrm{s} /{ }^{12}$ in the coda of the word-initial syllable is resyllabified in the onset of the following syllable; such cases yield phonetic (i.e. non-phonological) CCC- clusters:

\footnotetext{
${ }^{11}$ Where the occurrence of $[\mathrm{e}]$ is an instance of spelling pronunciation.

${ }^{12}$ Phonetically realized as [ [] as in European Portuguese.
} 
(63) estrondu [if.tron.du] ['ftron.du] 'din' < Portuguese estrondo

Resyllabification follows the model provided by European Portuguese, in which "vowels may [...] be deleted when they occur in unstressed syllables" (Massini-Cagliari et al., 2016, p. 62).

\section{Stress placement}

In Tetun Terik, stress falls mostly on the penultimate syllable ${ }^{13}$, but word-final stress is also attested (Costa, 2011a, p. 24; Williams-van Klinken et al., 2002a, p. 12, 2002b, p. 9; de Albuquerque, 2011a, p. 92-93). Portuguese loanwords have introduced a third possible type, i.e. antepenultimate stress. Consider the following examples:

(64) a. múzika 'music' < Portuguese música

b. polísia 'police' < Portuguese polícia

c. úmidu 'humid' < Portuguse húmido

According to de Albuquerque (2011a, p. 92), however, "falantes não-escolarizados" produce forms with penultimate stress" and produce forms such as:

(65) a. animál [a.'ni.mal] 'animal' < Portuguese animal

b. ipóteze [i.po.'te.ze] 'hypothesis < Portuguese hipótese

The account suggested here is that antepenultimate stress reflects the influence of European and/or Brazilian Portuguese, whereas the rightward stress shift, i.e. the occurrence of penultimate stress, should be traced to East Timor Portuguese. As noted by de Albuquerque (2011b, p. 74; 2011c, p. 235; see also de Albuquerque 2014a), "até palavras que possuem a acentuação gráfica não-penúltima são realizadas como paroxítonas" [= even words which have a non-penultimate graphic stress are realized as paroxitones, translation mine], as seen in the example below:

(66) cômico [ko.'mi.ku] 'graceful'

Summing up, cases such as those illustrated in (65) and (66) reflect the tendency of many speakers towards rightward stress shift, which brings Portuguese loanwords with either final stress or antepenultimate stress in line with words from the native stock.

13 The Austronesian and Papuan languages spoken in Timor-Leste exhibit predominantly penultimate word stress (see Zanten \& Godemans, 2007). 


\section{Discussion and conclusions}

The findings in sections 3 through 9 are summarized in Table 5:

Table 5: Portuguese influence on the phonology of Tetun Dili

\begin{tabular}{|c|c|}
\hline Characteristic & Source \\
\hline imported consonantal phonemes $/ p, v, \int, 3, n, K /$ & $\begin{array}{l}\text { European and/or Brazilian } \\
\text { Portuguese }\end{array}$ \\
\hline $\begin{array}{l}\text { phonologicalcontrasts /f/-/v/, /f/-/b/, /f/-/p/, /s/- } \\
\mid \mathrm{z} /, / \mathrm{s} /-/ \mathrm{J} /, / \mathrm{z} /-/ 3 /, / \mathrm{n} /-/ \mathrm{n} /, / \mathrm{l} /-/ \mathrm{K} /\end{array}$ & $\begin{array}{l}\text { European and/or Brazilian } \\
\text { Portuguese }\end{array}$ \\
\hline denasalization of vowels & East Timor Portuguese \\
\hline monopthongization & East Timor Portuguese \\
\hline replacement of labio-dentals with bilabial stops & East Timor Portuguese \\
\hline allophones [y] and [x] of // & East Timor Portuguese \\
\hline depalatalization of / $/$ / and /3/ & East Timor Portuguese \\
\hline depalatalization of $/ \mathrm{n} /$ and $/ K /$ & East Timor Portuguese \\
\hline allophone $[\mathrm{e}]$ of /a/ & Brazilian Portuguese \\
\hline $\begin{array}{l}\text { nasalization of vowels preceding a nasal onset } \\
\text { consonant }\end{array}$ & Brazilian Portuguese \\
\hline allophone []] of $/ z$ / & European Portuguese \\
\hline allophone [3] of /z/ & European Portuguese \\
\hline allophone [z] of /s/ & $\begin{array}{l}\text { European and/or Brazilian } \\
\text { Portuguese }\end{array}$ \\
\hline Allophone [t] of /I/ & European Portuguese \\
\hline new word-initial consonant clusters & All three varieties of Portuguese \\
\hline new word-medial consonant clusters & $\begin{array}{l}\text { European and/or Brazilian } \\
\text { Portuguese }\end{array}$ \\
\hline antepenultimate stress & $\begin{array}{l}\text { European and/or Brazilian } \\
\text { Portuguese }\end{array}$ \\
\hline rightward stress shift & East Timor Portuguese \\
\hline
\end{tabular}

The Tetun and Portuguese components of Tetun Dili are less strictly separated on phonological grounds than hitherto assumed. The evidence of separation includes: imported consonantal phonemes, see section 4; new word-initial and word-medial consonant clusters, see section 8; antepenultimate stress, see section 9. Indeed, these are all attested only in Portuguese loanwords. Also, Portuguese loanwords cannot serve as bases for prosodically motivated partial reduplication and truncated compounds (Avram, 2007, 2008). However, unlike other languages, e.g. Japanese in 
which loanwords are strictly separated from other lexical strata (Avram, 1993 and 2005), there is also evidence of partial integration of the two components of Tetun Dili, e.g. the extension of allophonic rules to words from the native stock, illustrated in 7.3 and 7.4 .

The variety of Tetun Dili which is most influenced by European and/or Brazilian Portuguese is illustrative of category (4) "strong cultural pressure: moderate structural borrowing" in Thomason \& Kaufman's (1988, pp. 74-75) scale of borrowing. The structural effects typical of this category include: new phonemes; new phones; new allophonic rules; new syllable structure features; new stress rules. These are precisely the structural effects amply illustrated in sections 4, 6, 7, 8 and 9 respectively.

As repeatedly shown in sections 3 through 9, there is considerable inter-speaker variation in Tetun Dili phonology. In previous analyses of the Portuguese impact on the phonology of Tetun Dili, this variation has been correlated with the extent of Tetun Dili-Portuguese bilingualism (in particular, Greksáková, 2018, pp. 324-350; see also de Albuquerque, 2010b, 2011b, 2011c, 2014a). However, as shown in the present paper, it also reflects the coexistence of conflicting exo-normative and endo-normative orientations, the former towards European and/or Brazilian Portuguese, the latter towards East Timor Portuguese. This accounts for the occurrence of contradictory tendencies. The examples discussed in 6.1 and 7.2 are a striking example of the clash between conflicting norms. As shown in 6.1, under the influence of the East Timor variety of Portuguese, the nasal vowels in Portuguese loanwords undergo denasalization. On the other hand, some speakers appear to have borrowed the allophonic rule of Brazilian Portuguese, whereby stressed vowels preceding a nasal onset consonant are nasalized, as illustrated in 7.2. Similarly, while many speakers do not have $/ \int /$ and $/ 3 /$ in their inventory of consonantal phonemes, as seen in 4 , others borrowed the allophonic rules of European Portuguese whereby /s/ and / $\mathrm{z} /$ are realized in coda position as [f] and [3] respectively, and - as shown in 7.3 - extend them even to words from the native stock. The situation is further compounded by the occasional occurrence of instances of spelling pronunciation, see 6.1. and 8.3, in which the phonetic realizations of some loanwords reflect their orthography in Portuguese. Summing up, the general picture that emerges is a complex one and the intricacies of inter-speaker variation cannot therefore be merely reduced to variation between a more Portuguese-like phonology and a more Tetun-Dili-like one.

\section{References}

de Albuquerque, D. B. (2010a). Elementos para o estudo da ecoliguística de Timor Leste. Domínios da lingu@gem, 4(1), 21-36.

de Albuquerque, D. B. (2010b). Peculiaridades prosódicas do português falado em Timor Leste. ReVEL, 8(15), 270-285. 
de Albuquerque, D. B. (2011a). Esboço grammatical do Tetum Prasa. MA thesis, Universidade de Brasília.

de Albuquerque, D. B. (2011b). O português de Timor-Leste: contribuições para o estudo de uma variedade emergente. Papia, 21(1), 65-82.

de Albuquerque, D. B. (2011c). O elemento luso-timorense no português de Timor-Leste. ReVEL, 9 (17), 226-243.

de Albuquerque, D. B. (2012). Esboço morfossintático do português falado em Timor-Leste. Moderna Språk, 1, 1-10.

de Albuquerque, D. B. (2014a). Restrições métricas da língua Tetun no português falado em Timor-Leste: o acento e a variação. In J. S. Magalhães (ed.), Linguística in Focus 10: Fonologia, 73-90. Uberlândia: Editora UFU.

de Albuquerque, D. B. (2014b). A língua portuguesa em Timor-Leste: uma abordagem ecoliguística. PhD dissertation, Universidade de Brasília.

de Albuquerque, D. B. (2015). Contatos linguísticos em Timor-Lest: mudanças e reestruturação. Percursos Linguísticos, 5(11), 68-89.

de Albuquerque, D. B. (2018). Ensaios de ecolinguística aplicada. Brasília: Anderson Nowogrodzki da Silva.

de Araújo e Corte-Real, B. (1990). A Contrastive Analysis between Tetun and English Consonants - A Preliminary Study of Some Phonological Features of Both Languages. BA thesis, Universitas Kristen Satya Wacana, Salatiga.

Avram, A. A. (1993). Împrumuturile recente şi fonologia limbii japoneze. Studii şi cercetări lingvistice, $\operatorname{XLIV(3),~191-200.~}$

Avram, A. A. (2003). Influenţa portugheză asupra limbii tetum. Paper presented at the Symposium of the "Iorgu Iordan - Al. Rosetti" Institute of Linguistics, 4-5 November 2003, Bucharest.

Avram, A. A. (2005a). Contacte lingvistice şi limbi mixte bilingve. In S.-M. Ardeleanu, G. Moldoveanu, G. Jernovei (eds.), Limbaje şi comunicare. Colocviul Internaţional de Ştiinţe ale Limbajului, ediţia a VII-a, Cernăuţi 2003, 193-204. Suceava: Editura Universităţii din Suceava.

Avram, A. A. (2005b). Fonologia limbii japoneze contemporane. Bucharest: Editura Universităţii din Bucureşti.

Avram, A. A. (2007). Reduplication in Tetun Dili. In A. Cuniţă (ed.), Concepts trans- et interculturels/Concepte trans- şi interclturale, Lingvistica, 165-187. Bucharest: Editura Universităţii din Bucureşti.

Avram, A. A. (2008). An overview of reduplication and compounding in Tetun Dili. Revue roumaine de linguistique, LIII(4), 427-448.

Avram A. A. (2018). Some aspects of the Portuguese influence on the syntax of Tetun Dili. In C. Lupu, A. Ciolan \& A. Zuliani (eds.), Omagiu Profesorilor Florica Dimitrescu şi Alexandru Niculescu la 90 de ani, 41-55. Bucharest: Editura Universităţii din Bucureşti.

Chen, Y.-L. (2015). Tetun Dili and creoles: Another look. University of Hawai'i at Mānoa Working Papers in Linguistics, Department of Linguistics, 46(7), 1-33.

Costa, L. (2001a). Dicionário de Tétum-Português. Lisbon: Edições Colibri.

Costa, L. (2001b). Guia de conversação Português-Tétum. Lisbon: Edições Colibri. 
Crowley, T. (1997). An Introduction to Historical Linguistics, 3rd edition. Oxford: Oxford University Press.

das Dores, R. (1907). Diccionario teto-português. Lisbon: Imprensa Nacional.

Esperança, J. P. T. (2001). Estudos de linguística timorense. Aveiro: SUL - Associação de Cooperação para o Dezenvolvimento.

Greksáková, Z. (2018). Tetun in Timor-Leste: The Role of Language Contact in its Development. $\mathrm{PhD}$ dissertation, Universidade de Coimbra.

Hajek, J. (2007). Language contact and convergence in East Timor: The case of Tetun Dili. In A. Y. Aikhenvald \& R. M. W. Dixon (eds.), Grammars in Contact: A Cross-linguistic Typology, 163-178. Oxford: Oxford University Press.

Hajek, J., \& Tilman, A. V. (2008). East Timor phrasebook, $2^{\text {nd }}$ edition. Footscray: Lonely Planet Publications.

Hull, G. (2000). Historical phonology of Tetum. Studies in Languages and Cultures of East Timor 3: 158-212.

Hull, G. (2002). Standard Tetum English Dictionary, $3^{\text {rd }}$ edition. Winston Hills: Sebastião Aparício da Silva Project \& Instituto Nacional de Linguística (INL), Timor-Leste.

Hull, G. (2006). Concise English-Tetum Dictionary. Disionáriu Inglés-Tetun. Winston Hills: Sebastião Aparício da Silva Publications.

Loch, A. \& Tschanz, M. (2005). Kleines Wörterbuch Tetum-Deutsch Deutsch - Tetum. Hamburg: Helmut Buske.

Manhitu, Y. (2007). Kamus Indonesia-Tetun Tetun-Indonesia. Jakarta: PT Gramedia Pustaka Utama.

Massini-Cagliari, G., Cagliari L.-C. \& Redenbarger, W. J. (2016) A comparative study of the sounds of European and Brazilian Portuguese: Phonemes and allophones. In W. L. Wetzels, J. Costa \& S. Menuzzi (eds.), The Handbook of Portuguese Linguistics, 56-68. Malden, MA: Wiley Blackwell.

Mateus, M. H. \& D'Andrade, E. (2000). The Phonology of Portuguese. Oxford: Oxford University Press.

McColl Millar, R. (ed.). (2015). Trask's Historical Linguistics, $3^{\text {rd }}$ edition. Routledge: London and New York.

Operstein, N. (2010). Consonant Structure and Prevocalization. Amsterdam / Philadelphia: John Benjamins.

Paradis, C. \& Prunet, J.-F. (2000). Nasal vowels as two segments: Evidence from borrowings. Language, 76, 324-357.

Ross, M. A. (2017). Attitudes toward Tetun Dili, A Language of East Timor. PhD dissertation, University of Hawai'i at Mānoa.

Seara, I. C., Nunes, V.G. \& Lazzarotto-Volcão, C. (2011). Fonética e fonologia do português brasileiro. Florianópolis: Universidade Federal de Santa Caterina.

Smith, N. (1995). An annotated list of creoles, pidgins, and mixed languages. In J. Arends, P. Muysken \& N. Smith (eds.), Pidgins and Creoles. An Introduction , 331-374. Amsterdam / Philadelphia: John Benjamins. 
Taryono, A. R., Ibrahim, A. S., Rusmadji, O. \& Moehnilabib, M. (1993). Morfo-sintaksis Bahasa Tetum. Jakarta: Pusat Pembinaan dan Pengembangan Bahasa, Departemen Pendidikan dan Kebudayaan.

Taylor-Leech, K. (2009). The language situation in Timor-Leste. Current Issues in Language Planning, 10(1), 1-68.

Thomason, S. G. \& Kaufman, T. (1988). Language Contact, Creolization, and Genetic Linguistics.. Berkeley: University of California Press.

Thomaz, L. F. F. R. (2002). Babel Loro Sa'e. O problema linguístico de Timor-Leste. Lisbon: Instituto Camões.

Thomaz, L. F. F. R. (2010). Das Portugiesische auf Timor. Quo vadis, Romania?, 36, 16-46.

Troeboes, M., Khristian, T., Mboeik, S. J., Maryanto, S. \& Wibowo, S. (1987). Struktur Bahasa Tetum. Jakarta: Departemen Pendidikan dan Kebudayaan.

van Klinken, C. L. (1999). A Grammar of the Fehan Dialect of Tetun. An Austronesian Language of West Timor.

Williams-van Klinken, C. (2011). Tetun Language Course, $3^{\text {rd }}$ edition, with revised spelling. Dili: Peace Corps East Timor, Canberra: Pacific Linguistics.

Williams-van Klinken, C. (2015). Word-Finder English-Tetum Tetun-Ingles, $2^{\text {nd }}$ edition. Dili: Sentru Lingua, Dili Institute of Technology.

Williams-van Klinken, C., Hajek, J. (2016). Tetu-gés: Influésia portugés ba estrutura Tetun. In S. Smith, N. Canas Mendes, A. B. da Silva, A. da Costa Ximenes, C. Fernandes \& M. Leach (eds.), Timor-Leste: iha kontextu lokal, rejional no global / O local, regional e global / The local, the regional and the global / Lokal, regional dan global 2015, 32-36. Hawthorn: Swinburne Press.

Williams-van Klinken, C. \& Hajek, J. (2018). Language contact and functional expansion in Tetun Dili: The evolution of a new press register. Multilingua, 37(6), 613-647.

Williams-van Klinken, C., Hajek, J. \& Nordlinger, R. (2002a). Tetun Dili: A Grammar of an East Timorese Language. Canberra: Pacific Linguistics.

Williams-van Klinken, C., Hajek, J. \& Nordlinger, R. (2002b). A Short Grammar of Tetun Dili. Munich: Lincom Europa.

Zanten, E. \& Goedemans, R. (2007). A functional typology of Austronesian and Papuan stress systems. In V. J. Heuven \& E. Zanten (eds.), Prosody in Indonesian Languages, 63-87. Utrecht: LOT. 